\section{Alkisti Efthymiou in Conversation with Athena Athanasiou: Spectral Publics and Antifascist Eventualities}

Bionote: Athena Athanasiou is Professor of Social Anthropology and Gender Theory at Panteion University of Social and Political Sciences (Athens, Greece). Among her publications are the books: Agonistic Mourning: Political Dissidence and the Women in Black (Edinburgh University Press, 2017); Dispossession: The Performative in the Political (with Judith Butler, Polity Press, 2013); Crisis as a "State of Exception" (Athens, 2012); Life at the Limit: Essays on Gender, Body and Biopolitics (Athens, 2007). She has been a fellow at the Pembroke Center for Teaching and Research on Women, at Brown University, and at the Center for the Study of Social Difference, at Columbia University. She is a member of the editorial advisory board of the journals Critical Times, Feminist Formations, Philosophy and Society, and Journal of Greek Media and Culture.

\section{Panteion University of Social and Political Sciences athenaathanasiou@panteion.gr}

Bionote: Alkisti Efthymiou is a Ph.D. candidate in the Department of Social Anthropology at Panteion University of Social and Political Sciences (Athens, Greece). Closely engaging with works of film, her thesis focuses on the critical state of intimacy under late capitalism. She holds a BA in Media and Cultural Studies and MA in Gender, Society and Politics from Panteion University, as well as an MA in Museum Studies from University College London. Her most recent publications include papers in the Greek feminist journal feministiqá and the Journal of Greek Media and Culture. She has received a scholarship to support her doctoral studies from NEON Organization for Culture and Development and the Hellenic Foundation for Research and Innovation (HFRI).

\section{Panteion University of Social and Political Sciences} alkisefth@gmail.com

Abstract: This text is a conversation between Athena Athanasiou and Alkisti Efthymiou, drawing from Athena Athanasiou's new book, Agonistic Mourning: Political Dissidence and the Women in Black (Edinburgh University Press, 2017). The conversation discusses the critical potency of collective subjectivities such as the Women in Black and expands on issues that include political agency, vulnerability in resistance, spacing appearance, performing public mourning, or the traveling of social movements, associating them with contemporary feminist and antifascist urgencies. Central to the text is the concept of non-sovereign agonism, a form of political agency that addresses (or takes into account) the dispossessed quality of subjectivity and pays attention to the relationality through which we are constituted as subjects.

Keywords: Women in Black, public mourning, memory, political agency, relationality, social movements

Alkisti Efthymiou: The politics of the transnational feminist and anti-militarist movement Women in Black and specifically its Serbian branch [Žene $u$ crnom] is an important point of engagement in your work. ${ }^{1}$ During the Yugoslav Wars in the 1990 , these activists publicly acknowledged and mourned, through wearing black and standing in silence, the dead from all "sides," undermining at once the normative associations of mourning with femininity and the dominant conceptions of nationalist sovereignty. Could you tell us a bit more about the context in which you encountered the Women in Black and bonded with their activism?

Athena Athanasiou: Although I had met with activists from the Serbian branch of Women in Black during my initial short stay in Belgrade in May 2005, I met again members of Žene u Crnom (hereinafter $Z \check{u} \cup$ ) in Jerusalem, at an international conference of Women in Black, in August of the same year. That first visit to Palestine allowed me to experience Israel's colonizing policies in practice. Palestinian villages and communities were divided, military checkpoints across occupied East Jerusalem and throughout the West Bank were disciplining Palestinian circulation. Together with my ŽuC friends and

${ }^{1}$ Women in Black is a worldwide movement opposing militarism, violence and war, and counting vigils in multiple countries such as Israel, Serbia, South Africa, India, Spain, and Australia. In this text, we focus on its Serbian branch, Žene $u$ crnom, which on October 9, 1991, initiated a public protest against the then ongoing Yugoslav Wars. For more information, refer to the website: http://womeninblack.org/vigils-arround-the-world/europa/serbia. 
comrades we marched through the streets of villages in protest against militarization and the construction of the Separation Wall, we took bus journeys to the West Bank, and held anti-occupation demonstrations at military checkpoints.

I was already aware of the feminist political interventions of Women in Black during the violent breakup of Yugoslavia, but my political bond with the antiwar feminist activism in former Yugoslavia was wrought, suggestively, in Palestine. That encounter was inscribed in the transnational and decolonial genealogy of the group, as the feminist antimilitarist organization Women in Black emerged in Jerusalem in January 1988, right after the beginning of the first intifa$\mathrm{da}$, when a small group of Israeli Jewish women on the Left, actively supported by Palestinian women, started marching into the West Bank to protest against the occupation.

Whilst I was writing Agonistic Mourning, and doing the research that became the book, ${ }^{2}$ the trope of the "other side" was acquiring a very intensive, personal, as well as political, meaning for me and for my own formative moments of critical positionality; most notably, a meaning of foreignness and not-being-at-home-in-theworld because of racism, sexism, heteropatriarchy, class privilege, and ableism. The political formulation of the "other side" resonated with the way in which I had experienced my own ex-centric positionality vis-à-vis nationalist scripts, gender norms, and my life as a feminist academic working in/for a public institution that I have found myself both defending from neoliberal depletion and, at the same time, inhabiting critically to cope with and struggle against its overwhelming national, class, and heteronormative markers of privilege. So, the political formulation of the "other side" became an ethnographic and auto-ethnographic device for reaching and relating to my friends in Belgrade and other places in formerYugoslavia. It became a site of comradeship and situated knowledge formed in the shared experience of unbelonging.

AE: You seem to be hinting towards an understanding of the "other side" as not merely one part of a binary opposition. Could you perhaps expand on that? And specifcally in relation to the Women in Black: Why were their protests so potent and critical in the histori-

${ }^{2}$ Athena Athanasiou, Agonistic Mourning: Political Dissidence and the Women in Black (Edinburgh: Edinburgh University Press, 2017). cal context of Slobodan Milošević's regime in Serbia and its conflicts with the "other side"?

AA: I met my Women in Black friends through sharing stories of the "other side," as we moved across and even against boundaries and orientations. My sense is that the concept of the "other side" is not merely a spatial issue, as Sara Ahmed has so powerfully shown in taking up the concept of orientation to queer phenomenology. ${ }^{3}$ She talks about how the "table" (especially the fraught figure of the dining table) matters in the ways our bodies are shaped, act, follow (straight) lines or become oblique. Surely, one occasionally has to go to another side, to the other side/s, or to what is other to available sides, to reach points from where to face the world beyond the straight order/ing of things. So, for me, taking sides takes place as a performative way of taking a stand by means of inhabiting (and "cohabiting," following Arendt and Butler) the polis and the world. ${ }^{4}$ In this sense, it involves the bodily disposition of decentering the authorized lines along which we are interpellated to position ourselves.

The political subjects with whom I worked use the trope of mourning as a means to publicly position themselves not along the authorized lines of gender, kinship and national normative belonging, but rather on the side of the other. Clearly, in the historical context of Slobodan Milošević's regime in Serbia, the ŽuC way of performing public memory and mourning for the ungrieved enemies of the nation, and doing so from a gendered internal enemy perspective, represented a treasonous deviation from, and a bodily refashioning of, the national and gendered propriety of mourning and memory.

So, in the situated epistemology of $\check{Z} u C$, the act of becoming the gender-marked enemy in the face of national mobilization signaled a feminist resistance to the idealized commands of patriotic kinship and motherhood. Standing at and across the border of the nationally defined body politic, ŽuC activism embodied the question of what happens when the one who does not belong returns to reclaim what Hannah Arendt calls "a space of appearance."

3 Sara Ahmed, Queer Phenomenology: Orientations, Objects, Others (Durham, North Carolina: Duke University Press, 2006).

4 Judith Butler, "Precarious Life, Vulnerability, and the Ethics of Cohabitation," The Journal of Speculative Philosophy, Vol. 26, No. 2 (2012), 134-51.

${ }_{5}$ Hannah Arendt, The Human Condition (Chicago: University of Chicago Press, 1958). 
AE: What is lost, if it is, when a movement that emerged in a particular spatial and temporal locality becomes worldwide (such as Women in Black, for example, that initially emerged in Israel in 1988 and spread to Serbia and globally)? Is a certain "moving" required for political gestures/actions of resistance to become "movements"?

AA: The question is what is lost, if it is, and what is gained when political ideas, concepts and practices travel. And then the question also becomes what can be lost in "winning," or what we gain through loss and through the risk of losing certitude and troubling attachments. To address the entire scope of this question is an impossible task here, but I would like to point out that the logic of moving can have a strange link with canonical definitions of routes and destinations, but also, more interestingly for me, it implies that a sign, an identity category or a political idiom can indefinitely (albeit not limitlessly) break with its given, authorized context and engender new contexts. Posed in these terms, the question of what can be lost on the way might take into account the performative event of citationality, whereby turns, wanderings, disorientations and re-appropriations form the lexicon of a non-linear and non-univocal bodily political life.

Hence the theme of "moving" transforms itself into a question of the embodied political and the possibility of its re-orientation. I think it would be interesting to think further how enacted agonistic politics describes a political agency that transfigures legacies of disposability through the performative textures emerging from the affective exposure of bodies in proximity of others. If refusing to stay in one's proper place can signal acts of resistance, critical agency can also "take place" in the form of claiming the right to stay in place, as in combating the colonially embedded logic of disposability/displace-ability, demanding one's rights in land, and claiming livable and affordable housing. ${ }^{6}$ Moving beyond the powers by which we are constituted does not have to involve geographical movement and determined localities. It may as well define manifestations of inhabiting and moving whereby geographical typologies and ontopologies (to recall Derrida's way of linking notions of being to notions

${ }^{6}$ Judith Butler and Athena Athanasiou, Dispossession: The Performative in the Political (Cambridge, UK: Polity, 2013). of place, locality, or territory ${ }^{7}$ ) falter and fall apart. The equation of agency with the capacity to move and mobilize rehabilitates the presumption that political praxis belongs to certain regimes of status, bodily morphology, and affective disposition, and it needs to be problematized from the perspective of deportability, statelessness, homelessness, struggles over land rights, and disability studies/crip theory. We have to continue to think what possibilities and articulations of political agency can be put forward by bodies-in-place and bodies-out-of-place as they reinhabit and transform normative matrices of embodiment, situatedness, public appearance and belonging/unbelonging.

So it seems to me that it would be interesting and fruitful to pursue the question of "locality" through the perspective of translocal and transversal performativity such as, for instance, the one pertaining to the movement of ŽuC in former Yugoslavia and the way it was inspired by, and traveled from, Israel/Palestine. I believe it is helpful to work with a critical framework that would enable us to productively question both the erasure of local/translocal specificity in Euro-American paradigms of universalist scholarship and the essentialist invocation of reified localization as an authenticated critical point of view of colonial capitalist globalization. The critical strands of thought that have been brought forward by feminist transnationalism, queer of color critique, and postcolonial/decolonial critique, have powerfully grappled with the tangled affective and political economies of location across geographical and epistemological boundaries. Drawing on such critical epistemologies, I am interested in how queer and decolonial locations and translocations can productively disorient our perspective, but also, perhaps more significantly, how concepts and political ideas and acts, when traveling across disparate topographies and temporalities, can work to queer and decolonize the politics of location and positionality.

The cross-border work of Women in Black entails not only crossing in spatial terms, but also performing acts of gender exile as a way to define a restless and transformative field of politics. These border-crossings are about affirming a critical cartography of interstic-

7 Jacques Derrida, Specters of Marx: The State of the Debt, the Work of Mourning and the New International, trans. by Peggy Kamuf (London: Routledge, 1994), 126. 
es and interfaces, and thus changing the normative premises that form the inscriptional space of locality, belonging, borders, and the nation-state.

So, to answer your question whether a certain "moving" is required for political gestures of resistance to become "movements," I would say that "moving" does not have to be taken literally and it does not necessarily move "straight." It does not have to follow straight lines (as well as straight timelines) of a fixed and immediate order. It does not have to affirm transparent and univocal identities or preconfigured and essentialized subjectivities and communities. Through a perspective of political performativity, claiming a place is not merely about inhabiting what already exists but rather about re-appropriating, repurposing and transforming place through troubling and thwarting racialized, sexualized, and economized onto-epistemologies of emplacement and displacement. In this sense, it seems to me that it is crucial to continue working toward a non-foundational theory of locality and movement in order to account critically for the contingent ways in which universalized structures of inhabiting and moving are confounded, affective and bodily morphologies are critically dispossessed, and political practices are reimagined. And so I think we need to continue defending critical theory's different genres of nuanced complexity.

$\mathrm{AE}$ : The translocality of Women in Black brings in mind, perhaps a bit arbitrarily, the rapid global spread of contemporary mobilizations like \#MeToo. Talking about "movement," do you think there is something to be said here about the type of feminist critique that \#MeToo seems to "move" around the world?

AA: I wonder whether and how one can draw together Women in Black and \#MeToo, given that these are incommensurably disparate instances and I would not want to pose an airtight comparative frame here. I think, however, that a transnational, ex-centric, non-US-based perspective would offer valuable insights into the multiple ways in which constellations of gendered violence play out in different contexts of colonial, patriarchal, and capitalist power. I am thinking, for example, of the feminist movement Ni Una Menos, which, through open assemblies and other genres of organized resistance, has articulated a response to the growing number of femicides in Argentina.
Surely \#MeToo is a broad mobilization, which, importantly, has prompted awareness and dialogue about harassment, abuse, and hierarchical manipulation in the workplace. I support the gesture of making oneself part of a broader collective subjectivity and standing with others to acknowledge shared suffering and anger, to struggle against ubiquitous and normalized structural forces of misogyny, and to put forward collective visions for worlds of justice and equality.

I wonder, however, whether \#MeToo could exceed the caliber of white US individualist feminism. I am hesitant in front of what I understand as rehabilitation of a non-intersectional universal - or universalizable - female "me" that reproduces the structure of capitalist individualism: a "me" that seems to be inscribed in the longstanding marginalization of women of color, trans women, gender non-conforming people, and those in undervalued fields of work within the larger US feminist movement. It is worth recalling that the phrase which was used by actress Alyssa Milano as a Twitter hashtag in response to allegations of sexual assault by Hollywood producer Harvey Weinstein had been initiated by African American activist Tarana Burke in 2006, and was influenced by black feminist scholars such as Kimberlé Crenshaw whose work on intersectionality called for a new way of addressing the combined effects of racism and sexism in the lives of black women. ${ }^{8}$ We might need to ask why the phrase gained widespread attention recently. And so we have to look at the situation we are currently in, and I think the answer would be rather complicated.

I would say that this is, once again, a necessary time to counter the pervasive ordinariness of gendered assault and injury in the historical present, while tracking new modes for responding to it. When it comes to the need to expose and unsettle, again and again, the banalized intelligibility of violence, I would like us to be able to think collectively on how social structures of unrelenting, normalized heteropatriarchy can attract attention and public awareness. And

${ }^{8}$ Nataša Petrešin-Bachelez, "Practice Intersectionality," L'Internationale (May 27, 2018), https:// www.internationaleonline.org/research/politics_of_life_and_death/103_practice_intersectionality.

Allyson Hobbs, "One Year of \#MeToo: The Legacy of Black Women's Testimonies," The New Yorker (October 10, 2018), https://www.newyorker.com/culture/personal-history/one-year-ofmetoo-the-legacy-of-black-womens-testimonies/amp?_twitter_impression=true. 
I would like us to think critically about the different ways logics of "proper victimhood," moral indignation, sentimental identification, and the register of the mass cultural intimate public play out in this \#MeToo moment. I have in mind Lauren Berlant's groundbreaking work on the genre of "the female complaint" as part of the "unfinished business of sentimentality in American culture," where she addresses the link between intimacy and publicity in ways that dissect the category of individuality in late capitalism. ${ }^{9}$

Also, as we ponder the question who gets to speak and who gets to be heard in these mass-mediated publics, we might need to think further about the distinctions and indistinctions between individual denunciation and political testimony, as well as between public accountability and publicity stunts in the techno-optimistic era of shorthands and "likeability." Finally, as we seek justice, we might ask ourselves: how do we involve (or do not involve) the legal/punitive machinery of incarceration? Is the current lexicon playing out in the \#MeToo moment sufficient for addressing the intersections of power and violence? And then how to critically engage with political ramifications that \#MeToo obscures?

What I am trying to say is: could we complicate the conversation, or would this move get us into trouble? I worry that the current global rise of the forces of racial capitalism and national right fosters the sentiment that complicated critical reflection is an irrelevant distraction at this moment of urgency. In that respect, I would keep in mind the current backlash against poststructuralist thought, along with trends of anti-critique and rebukes of "relativism" and complexity, at this intense moment of unleashed racism, misogyny, anti-immigration, homophobia/transphobia, anti-Semitism, and Islamophobia.

With that said, I am quite perplexed when what travels under the name of feminism sometimes takes the form of a white bourgeois heteronormative regime of truth. It makes me remember that feminism is certainly not immune to being consumed by racial capitalism and to acknowledge the multiple feminist antiracist practices that resist this peril in different contexts of this world. I think we need

${ }^{9}$ Laurent Berlant, The Female Complaint: The Unfinished Business of Sentimentality in American Culture (Durham, North Carolina: Duke University Press, 2008). courageous transnational critical theory to inspire, historicize, and think differently about the ways we agonize and organize in and against the toxic atmospheres generated by the intersecting structural powers of racial, sexual, national, and class privilege. We need the courage of critical theory to open up spaces for change. That is hard work, I know, and it is collective through and through.

AE: ŽuC activists stood still and in silence in the Republic Square of Belgrade. They demonstrated their opposition to the war, wearing black as the colour of grief to mourn those posited as impossible to mourn according to the requirements of nation and war. As you mention in your book, this "mourning" can be termed as such "only by virtue of political catachresis," echoing Judith Butler and her work on the figure of Antigone. ${ }^{10}$ Could you elaborate on this idea? How does it interrupt conventional allegiances of gender, sexuality, and nation?

AA: Indeed, the political grief of Women in Black, bringing into play several kinds of possibilities and impossibilities, resignifications, and aporias, has nothing to do with a nihilistic despair of tending the dead. Rather, it is about troubling the intelligibility of memorability by means of public, embodied affectivity and performativity. In a way, the act of taking mourning beyond kinship and national normativity moves this political activism beyond mourning as well. In working with them, I have been interested in understanding the ways in which these political subjects, acting in the context of a multilayered antimilitarist, antifascist and queer feminism, have been embodying the political and ethical eventualities involved in their own and others' dissident un/belonging. I was interested in this queering going on in the very complexities and complicities of belonging. By "queering" I mean here the acts of disrupting the (ethno-nationalist and heteronormative) conditions of intelligibility that mark grief, camaraderie, dissent, and transformative desire in the face of political loss.

In this sense, performing grief, relationality, and political agonism beyond the mourning's biopolitical matrices of gender and national properness entails a political catachresis, that is, the strained

${ }^{10}$ Judith Butler, Antigone's Claim: Kinship Between Life and Death (New York: Columbia University Press, 2000) 
and deformed/deforming appropriation of a signifier in contexts that would be perceived as inappropriate. The ŽuC activists mourn where and when they should not; they mourn in inappropriate ways and for inappropriate purposes. What would this transposition and reconfiguration against the grain do to the power relations that have authorized and validated prior uses of this sign? It seems to me, and I am inspired here by the work of Judith Butler and other scholars of gender performativity, that this acknowledgement, recollection, and recitation of historicity opens up spaces for the possibility to undermine and politically transform those authorizations. These spaces have their own internal limits, of course, and their own vulnerabilities to injurious effects. I think it would be interesting to think of political performativity as not only an instantiation of breaking with prior contexts but also of critically recollecting and remembering them in ways that can hopefully be politically reparative and transformative. It seems to me that the complexities and complicities of agonistic mourning, as a resistant politics of remembering otherwise, affirm the links between subversion, vulnerability, recollection, and performativity. I have tried to elucidate that these interconnections are not reducible to any presumed and clear-cut symmetry between possibility and impossibility. For me, agonism complicates and troubles the presumed linear passage from potentiality to actuality, or from passivity to volition. In this sense, attending to the im/possible aspects of mourning has significant effects for acknowledging contingency and vulnerability at the heart of critique and political performativity.

AE: In your work, you problematize the notion of sovereignty, both as the militarized, unilateral power of the nation-state and the one of subjectivity based on the model of self-sufficiency, individualism, phallogocentrism. Instead, you introduce a different conception, talking about "non-sovereign political agency" and "sovereignty without sovereignty." Could you further describe this concept and its association with vulnerability and finitude? If this kind of subjectivity is so fragile and contingent, how can it be incorporated in contemporary struggles of marginalized groups that strive for recognition and self-determination?

AA: That is a key question, which hits at a real core. Let me make clear from the start that I think non-sovereignty as a conceptual de- vice at once affective and sociopolitical. Also, I would like to emphasize that the notion of non-sovereign subjectivity I seek to elaborate, while involving the modalities of vulnerability, is not a negative or nihilistic concept and is not reducible to destitution. Nor should it be equated to self-negation, although it seeks to question the liberal devices of individualistic selfhood. Rather, it is an experimental, critical lens through which to think (with) the relational as a way of decentering the self as well as universalized, ontological, dichotomous figurations of self/other. I believe that this idea has significant implications for our understanding of the political today. In my work, I have tried to reflect on the political acts of performing non-sovereign, agonistic political agency in opposition and resistance to the logics of abjection, racism and militarism.

Relevant to our conversation here would be Simone de Beauvoir's account of eroticism and erotic desire, which grounds itself in the alterity of the other. ${ }^{11}$ Of course, Beauvoir works with an existentialist theory of subjectivity as a transcendent movement, but I am interested in how a non-possessive ethics of reciprocity emerges from a different account of subjectivation, one that addresses the dispossessed quality of the subject and pays attention to the relations and norms through which we are shaped and situated as subjects. It seems to me that poststructuralist feminist thought has raised compelling questions for ethics. The way in which Butler reads Beauvoir (notably, Beauvoir's consideration of Sade with "critical sympathy," in Butler's terms) is very illuminating in this regard. ${ }^{12}$ I think we need to find ways of figuring reciprocity and responsiveness beyond self-sovereignty; and also without complementarity, universality, fetishization of the other and reduction of alterity to sameness (as in Hegelian reciprocity). Acknowledging the impossibilities of absolute reciprocity evokes new aporetic possibilities of intersubjective relationality that might disrupt the logic of the absolute.

When I seek a way to pay attention to non-sovereign political claims, I have in mind a certain mode of sovereignty: one predicated on the matrices of the self-contained, self-sufficient, and coherent subject, ${ }_{11}^{11}$ Simone de Beauvoir, The Second Sex, trans. by H. M. Parshley (New York: Alfred A. Knopf,
1953). Originally published in 1949.
${ }_{12}$ Judith Butler, "Beauvoir on Sade: Making Sexuality into an Ethic," in The Cambridge Companion
to Simone de Beauvoir, ed. by Claudia Card (Cambridge, UK: Cambridge University Press, 2003), 168-88. 
body politic, family or nation. Through histories of colonial capitalism, sovereignty has become the irreducible paradigm for social and political intelligibility. But I think it would serve us well to consider what other relations to the political are possible. The possibility of non-sovereign politics runs counter to the common conception that politics requires resolving or even negating, in some sense, the complicated and intractable messiness of subjectivity and subjectivation. Politics is almost automatically understood, primarily in Western liberal contexts, in terms of affirming one's sovereign identity. In contrast, through the space opened up by the problematization of sovereignty, the point would be to rethink relationality as a transformative political concept; and also as a possibility to rethink sovereignty itself. The point for me is to ask how we might think of sovereignty differently by remaining critical of self-sufficient and indivisible self-authorization. I certainly do not mean to do away with all sovereignty as such, especially insofar as this notion has been tied to collective claims of popular sovereignty or struggles of marginalized groups for recognition and self-determination. I would like to ask, however, whether we might reinscribe self-determination as embodied relationality for thinking and enacting political articulations.

AE: Certain feminist political subjectivities of today have developed their claims along the lines of "my body is my own," particularly in reaction to rape culture and sexual assault and harassment. Where does relationality and vulnerability fit into such claims?

AA: This is a very important question, especially given that the formulation "my body is my own" - as not merely a linguistic but also a political performative formulation - can take many forms in different registers, can be premised upon different standpoints, and can serve disparate interests. We must be able to distinguish these qualitative differences and assess in what direction they work in specific contexts of power relations. In our theories and practices, we have to always try to make sure that this political lexicon works to address and contest injustice, inequality, oppression, and, more specifically, the biopolitics of gender and race. As antiracist decolonial queer feminists, we are always attached to the long-standing urgency of the political project signaled by this formulation. As we hold onto this political articulation that has historically mobilized extremely important collective struggles, we are mindful that the formulation itself implies a politics of positionality and situated knowledge that points to a radically reformulated notion of embodied subjectivation. As long as bodies are deemed dispensable and disposable, we need to ask, again and again: How do bodies come to matter or do not matter as they become inscribed in the workings of power and enact contestation ${ }^{13}$

That said, I wish to contend that in the context of struggles against sexual violence, or against the abolition of women's reproductive and non-reproductive self-determination, countering the forces that challenge the possibility of being a self-determining sovereign subject becomes an occasion for concerted actions of political despair and dissent troubling the frames of proper (i.e., individualistic, hetero-patriarchal, white, possessive bourgeois) subjectivity. And yet, universalized feminist concerns with violence against women often replay normative modalities of "vulnerability" that have historically served biopolitical pursuits of women's "protection" from racialized others. One can also trace such essentialist productions of gendered "vulnerable bodies" in discursive formations that promote the criminalization of sex work as sexual violence exercised upon women's bodies.

My sense is that our political struggle is not about instating a logic of invulnerability or claiming an exemption from vulnerability seeking recourse to the grand narrative of the self-contained and securitized individual, but rather about struggling with, within, and against the power configurations that determine whose vulnerability and corporeal integrity counts. So I would like to emphasize that "vulnerability" itself undergoes an important conceptual and political reconfiguration when at stake are dissident acts of defending and politicizing vulnerability by those dispossessed of self-determination. This is a kind of theorizing, I think, that would take us beyond the abstract and universal generality of vulnerability and would have us challenge the overriding power differentials that determine the structural experience of becoming-vulnerable.

It may appear that the formulation "my body is my own" implies a claim of invulnerability. Contrary to such (mis)understanding, however, I take it as one possible way to critically assess how bod-

${ }^{13}$ Judith Butler, Bodies that Matter: On the Discursive Limits of "Sex" (London and New York: Routledge, 1993). 
ies come to matter, in Butler's terms. Our bodies are ours but also given over, never entirely our own, never entirely under our control; certain bodies are expelled, exploited, under-resourced, exhausted. Acknowledging, politically positioning, and thinking with vulnerability does not undermine but rather enables claiming rights of bodily self-determination even if our bodies are not simply our own. It seems to me that feminist ideas of corporeal vulnerability are intimately interconnected with, and indebted to, histories of feminist and queer aspirations and struggles for corporeal self-determination. Defending vulnerability as a relational capacity to affect others and to be affected by others should not doom anyone to cruelty and suffering. Consider the differential and unequal costs that we, as differently positioned subjects, have to pay for defending (our) bodies that are not our own. Defendability is not inexhaustible. The question is how we fight for the right to matter when our bodies are battlefields that are never simply our own in many senses; and how vulnerable bodies are mobilized mobilizing (their) vulnerability in order to politicize their injuries.

In contesting the differential distribution of precarity, different street actions and activist movements have performed the questions: Who comes together, whose streets, who has not been included in "the people," whose lives matter as lives? The Black Lives Matter movement, which was initiated by three young black feminists, organized public demonstrations where protesters held banners reading "Hands Up, Don't Shoot" and "I Can't Breathe," to convey a particular kind of racialized deadly violence and embodied disposability that black people experience in ways so thoroughly embedded in the ordinary. The "I Can't Breathe" phrase commemorated Eric Garner, who died from a chokehold applied by police officers while he pleaded for a breath of air eleven times, on July 17, 2014, in Staten Island, New York City.

Feminism allows us to politically mobilize this sense of suffocation as a site of critical and empowering resignification through which to call into question the vast power differentials of class, racialization, gender, sexuality, and able-bodiedness through which precarity is experienced. As the legacy of liberation movements by racialized and gendered subjectivities showcases, vulnerability can enable collective political praxes of revolutionary transformation. It becomes a contingent condition of political possibility.
AE: How have movements like Occupy or the Indignados changed the ways people gather together? In the case of Aganaktismenoi (Greek for Indignados) in Syntagma Square in Athens, a constant point for critique or provocation has been the co-existence (in the same public square but not in the same "zone" within the square) of right or even far-right groups and left or anarchist ones. I wonder if such a "co-existence" ameliorates the agonistic potency of the movement, depoliticizing it to an extent?

AA: This question points to a profoundly important issue. I see these movements as provisional planes of appearance and actualization. They are also planes of intensities and agonistic battle lines enacted in bodily performative terms. There is nothing pure, fixed and lucid about the composition of a "we," and the question "Who are 'we'?" is not to be answered through simplistic identitarian devices. For me, the task is to come up with ways of resisting the impulse to essentialize that coming-together. We have to be able to ask whether composing a "we" is even a unifying project and whether we want it to be such.

You are right to point out that the co-existence of so different constituents might work to produce depoliticizing effects. However, multiplicity and even awkward incoherence cannot be expelled from the political space of relationality. What matters for me is how we engage politically with this incoherent and inconvenient multiplicity. Such public gatherings can become transformative occasions for experimental socialities emerging in the cracks of capitalist individvalism. They can instantiate collective bodily engagement with precarity in the wake of commodification and dispossession of resources, health care, and housing. But they can also work to gloss over differential positionalities in terms of class, racialization, migration and refugee status, ability, and gender. They can work to produce others by creating a horizontal solidarity - a fraternity of grievances, as it were - defined by a white, middle-class, heteronormative, national "we" formed and affected by de-industrialization, especially given the global growing influence of racism and neo-Nazism.

Your question makes me realize that, when it comes to the political dynamics of public gatherings and movements, there is no master narrative to plan and determine the possibility of the social. In a rad- 
ical democratic perspective, such gatherings are themselves political interventions that have the capacity to foment thinking about the question of who has, maintains, claims and exercises the right to assemble ${ }^{14}$ who becomes silenced and publically imperceptible; what political possibilities are enabled or excluded. In a way, this constellation of questions implies and involves fighting for alternative ways to come together and to share distances, to imagine and to generate change. There is surely no guarantee about the outcome of this fight for reinventing lived democracy beyond the free market political and economic rationality. In this sense, I take the embodied relationality implicated in projects of making public presence to be an interminably complicated matter: both limited by various complexities, convolutions and incommensurabilities, and open to unexpected transformative political potential. For me, what is really important is what becomes unpredictably possible in the fissures - and often against the grain - of gatherings and the commons.

The interconnected forces of neoliberal restructuring and the rise of far right produce today a space of forming mass-marketed publics and popular cultures saturated by anti-political and anti-democratic sentiments, and organized around identitarian ideologies of racist, nationalist, reactionary anti-global, islamophobic, misogynistic, and homophobic/transphobic resentment. Speaking from the moment we presently inhabit, lots of "outraged" people's movements are reactionary. In certain contexts, it is the far right that capitalizes on the frustrations of the austerity-hit middle classes. In the US and in Brazil, white male supremacists did. In an increasing number of European countries, national exceptionalism, securitization and middle-class frustration are deployed as tools against "globalization." Far right-wing parties claim the power to promote an authoritarian order of white, Christian Europe. They campaign for a well-regulated capitalist order of things premised upon a flourishing (white, national) middle class status quo, which retains its normative fantasies of sovereignty and security against a world of strangers "with privileges." We have to keep in mind that the impoverishment of the middle class propelled the rise of fascism between the two world wars. Nicos Poulantzas, in his classic Fascism and Dictatorship, has delineated the relationship between fascism and the different fractions of the

${ }^{14}$ Judith Butler, Notes Toward a Performative Theory of Assembly (Cambridge, Massachusetts: Harvard University Press, 2015). bourgeois class, emphasizing that the operations and repercussions of these class contradictions and alliances impicit in the rise of fascism are not confined to economics alone or the military aspect. Here is a memorable passage from that book: "In this respect, Clara Zetkin's warning to the executive committee of the Comintern on 23 June 1923, is still correct: 'The error of the Italian Communist Party lies mainly in the fact that it has seen fascism only as a military-terrorist movement, not as a mass movement with deep social roots. It must be stressed that before fascism wins militarily, it has already won the ideological and political victory over the working class..."'15 The rise of the new fascist forces is not merely a repetition of the past but at the same time it is possible - and perhaps necessary - to trace continuities as well. Perhaps what is at stake here is engaging the nuanced ways in which history is performed in the present. The collective memory of left antifascism is, for me, an indispensable vantage point here. ${ }^{16}$

In other countries, such as Spain, Portugal and Greece, the Indignados movement was instigated in recent years by the common cause of resisting and opposing authoritarian austerity governments, although there was surely no univocal agreement over what kind of world those participating in the mobilization would envision to build. But there was a reconfigured political Left emerging and reassembling from that plural and heterogeneous movement that sought to critically reactivate democracy, to inspire a transformative social imaginary and to build on alternative aspirations for an anti-neoliberal, post-nationalist Europe. I think that if we are to think through and with the question of antifascist critical possibility in the present time, it is necessary to work with left and radical democratic configurations of political life that can be shaped in the present, within and beyond the present biopolitical order, and as claims for a different future.

The question of sustainability is also relevant in this regard. It is an important part of all dissident political forms to seek ways to make them sustainable. But again, how to understand and critically rethink the attachment to promises of duration? What other notions

\footnotetext{
${ }_{5}$ Nicos Poulantzas, Fascism and Dictatorship: The Third International and the Problem of Fascism trans. by Judith White (London and New York: Verso, [1970] 2018), 84

${ }^{16}$ See Enzo Traverso, The New Faces of Fascism: Populism and the Far Right (London and New York: Verso, 2019).
} 
of sustainability or notions alternative to sustainability - i.e., possibilities for non-linear, non-teleological, open-ended relationship to temporality and the world - might emerge and be enacted from responses to precarity through troubling the social norms of reproductive temporality? Ultimately, how does "crisis" work to conventionalize desires and modes of living and living on? These are all questions that call for a rethinking of ongoing crises and agency. For me, this requires us to attend to a critical politics of temporality that accounts for contingent acts that "brush history against the grain," in Walter Benjamin's terms, rather than eagerness to transcend conflict and to control history according to self-aggrandizing orthodoxies.

I also think that this matter resonates with your own work, Alkisti, on the cultural politics of intimacy as a critical state that bears radical potential for change under late capitalism. Perhaps for both of us the question would be how "crisis" becomes an occasion for critical worldmaking instead of complacent (self-)possessive and self-sufficient individualism.

AE: Indeed. To go a bit further with your argument, critical worldmaking goes hand in hand with forms of relationality (such as love, in my view) that can open up the subject to the possibility of its non-sovereignty. It would be interesting, I think, to ask to what extent this "opening up" happens in public protest. It seems that in order not to reinforce a metaphysics of presence, or fetishization of being-there, when talking about the polis and public assembly as spaces of appearance, we need to constantly be reminded of who might be excluded from such spaces and from appearance. Under this light, we would shift "from an analytics of spaces of appearance to one of spacing appearance," as you suggest in your book. What does such a shift entail and how does it relate to spectrality and counter-memorial work?

AA: In assembling in public space, bodies are interpellated to fulfil the conditions of possibility for their appearance through norms of gender, sexuality, nationality, raciality, able-bodiedness and ownership. And so embodied practices of critical agency might find themselves resisting the epistemological premises and differential conditions of "appearance." The need to constantly be reminded of who might be excluded from such spaces of appearance and who appears out of place (i.e., without holding onto the sovereignty of presence) is about recalling what remains of unhomely, displaced presence; it also gives counter-memory a place. Forming all that remains from the space of appearance, such absent presences complicate the ways in which people come together and emerge in contested spaces and in spaces that have been rendered uninhabitable, or opt out of certain schemes of appearance. It seems to me that the point of the "I am no longer here" sign (on one of the banners that appeared in the 2012 Gay Pride in Belgrade to commemorate LGBTQI+ people who were expelled from the public space) in this context is to account for bodies to which "appearance" is at stake. The available space of appearance is indelibly marked by those "no longer" that contest hegemonic memorability. The analytics of spacing appearance seeks to complicate the conditions of "being there" and "belonging together" through which political agency is typically articulated. Spacing collapses the clear distinctions between appearance and disappearance. It is perhaps the register of the emergent performed by bodies in political space. It attends to the political temporalities and spatialities that might arise from embodied practices of appearing out of place, or appearing in disappearance.

AE: From the "I am no longer here" sign that you mentioned to the photos of the dead body of the refugee child Alan Kurdi washed ashore: there are different ways in which the dead "appear" and, especially in the context of the so-called "refugee crisis," the dead have been used to construct "the suffering other" as exactly such. As a passive, helpless, mute body that, according to Leticia Sabsay, "demands affective responses willing to commit to humanitarian enterprises, thereby moralizing otherwise potentially political claims." ${ }^{17}$ Would you perhaps like to expand on these different forms of appearing and disappearing in relation to how the "living" engage with the "dead"?

AA: You are pointing to different registers of meanings, practices, affects and political engagements of bodies appearing and disap-

${ }^{7}$ Leticia Sabsay, "Permeable Bodies: Vulnerability, Affective Powers, Hegemony," in Vulnera bility in Resistance, ed. by Judith Butler, Zeynep Gambetti and Leticia Sabsay (Durham, North Carolina: Duke University Press, 2016), 280. 
pearing in/from quotidian public spaces. The "I am no longer here" banner asks a necessary question: What kind of partial, displaced and disavowed presence is implied through that which appears to be not there? It thus articulates a demand for a political reparation. Our task is to respond to this radical cry and acknowledge how it takes place, what takes its place, and what cannot take place except in a spectral fashion.

The Derridean critical framework of spectropolitics acknowledges the disquieting, uncanny persistence of the past that occupies present-day configurations of the political and opens it to the possibility of change. A few years ago, a wave of protests swept several US cities under the banner of "Say Her Name" to remember black women who were injured and killed by police violence and sexual assaults. Perhaps these tactics prefigure and spectralize a "space of appearance" (which I understand as different from a space of visibility), unexpectedly turning it into a site of collective potentiality for alternative imagining and enacting. Such sites and spaces are haunted by all those condemned to live as living dead. They are marked by situated knowledges such as the activist remembrance of the recent death of the queer activist and drag performer Zak Kostopoulos/ Zackie Oh after a brutal public beating in the center of Athens.

The structure of spectrality is also being taken up to address conditions of border securitization and refugee necropolitics in EU borderlands and to bring out the exigencies that mark the coming-into-presence of the body politic as a common or uncommon space in late capitalism. The presumptions of commonness are contested by economized, racialized and illegalized precarious lives rendered dispensable and deportable and haunting securitized neoliberal Europe. And so I could not agree more with Leticia Sabsay's account. For my part, I think this is a necessary critique of the compassionate liberalist impulse to moralize and depoliticize, and it is interesting to trace how compassionate/condescending liberalism converges with neoliberal border securitization masquerading as humanitarianism at a moment when walls and fences are rising and becoming increasingly militarized.

When it comes to humanitarian viewership, I think the question cannot be more urgent today. Indeed, what kind of visual and sensual familiarities and unfamiliarities are enacted when TV screens and social media are saturated with images of distant others in distress and refugee bodies "washed ashore"? Do these images become part of a visual field already entrenched in a securitarian epistemic violence that renders certain bodies unrecognizable or all too recognizable? Might they mobilize to political action despite and against realms of visual order and ordinariness that are infused with overlapping forms of oppression, including racism, heteropatriarchy, white supremacy and capitalist exploitation? What would it mean to assert a politics and poetics of opacity (as in Blanchot's "right to disappear") against the drive to visualize? ${ }^{18}$ And how might this be uncannily linked to the political duty to appear?

When it comes to the aesthetics of biopolitics, perhaps we would need to pay attention to the ways in which intersectional critical race feminist epistemologies have addressed the visual, sensational, and representational violence of the white male gaze. In our present global context of brutality against African-Americans ("walking while Black"), immigrants, refugees and queer and trans people, we might ask ourselves whether the visual economy of humanitarian governmentality is another trope of depoliticization and anti-politics, and how we can engage with a radical democratic articulation of the political premised upon agonistically reconfigured formulations of seeing, feeling, knowing, caring, responding and acting.

AE: One last, but very pertinent, question. Signed in June 2017, the Prespa Agreement between Greece and the Republic of Macedonia finally resolved the long-standing dispute over the latter's name, a dispute that echoes back to the 1990 s and recalls Greece's foreign politics during the Yugoslav Wars and the parallel rise of nationalism in the country. In the present conjuncture of the Agreement, do you see perhaps an intensified evoking of national sovereignty and, if so, how could forms of non-sovereign agonism, or agonistic democracy, resist it?

AA: In an international scene where the political spectrum shifts to the right, and in a Europe where anti-immigration sentiments and ethno-racist chauvinisms are surging in the debris of aggressive

${ }^{18}$ Maurice Blanchot. Michel Foucault as I Imagine Him in A Voice from Elsewhere, trans. by Charlotte Mandell (Albany, New York: State University of New York Press, 2007), 120. 
capitalist restructuring, the peaceful and equitable settlement of the decades-long dispute between the two countries over Macedonia's name is a radical democratic event that allows for, and does justice to, a new social imaginary of mutual self-determination in a post-nationalist and post-austerity Europe. For me, this critical event showcased that the ethico-political vision and courage of agonistic democracy can overcome sedimented configurations of ethno-nationalist power.

Although it has been a thorny issue in Yugoslav-Greek relations since World War II, the "name dispute" was reignited after the breakup of Yugoslavia and the declaration of independence from the former Socialist Republic of Macedonia in 1991. Nationalism was one of the leading forces that brought forth the overthrow of communism. It was the time when the Greek foreign policy aimed at destabilizing Macedonia (named under the then provisional reference "Former Yugoslav Republic of Macedonia" / FYROM), as it was manifested also in the alliance with the nationalist Serb leader, Slobodan Milošević, who played a leading role in the violent dissolution of multinational Yugoslavia. For the Greek diplomacy of the time, "FYROM"'s use of the "name Macedonia" signified nothing less than an irredentist threat to Greek national history, cultural heritage and territorial integrity.

The Prespa Agreement has sparked mass nationalist protests on both sides of the border. In both countries, demonstrators who railed against the accord described it as a national sellout. In Greece, the whole spectrum of conservative forces, ranging from the farright and center-right parties to the social-democrats and even the communist party (which insists that the settlement was brokered by NATO and the EU), responded to the signing of the Prespa Agreement with isolationist pride and conspiratorial resentment. The rally in Athens was marked by an operation of neo-Nazi groups that, shouting "scumbag traitor politicians" and using iron flagpoles as weapons, tried to storm the parliament.

In an uncanny way, these events took us back to the "rallies for Macedonia" that took place in Greece in the 1990s, under the major slogan "Macedonia is one and it is Greek." It was the time when clergy associations and reserve military officers invaded public life; when schools were shut down to "facilitate" the participation of students in the demonstrations; and when the Greek diaspora mobilized. In those rallies, the plural demos of democracy was hijacked by the self-enclosed community of blood ties (thus echoing the notorious slogan of Greek nationalism in the late nineteenth and twentieth centuries: "Fatherland, religion, family").

In December 1992 in Athens, a few months after the Thessaloniki rally, the neo-Nazi organization Golden Dawn made its first open and violent public appearance, by transforming the "common sense" of national supremacy into a racist weapon of hatred against those who did not seem to fall into its standards of the (white Christian masculine) "proper Greek." In November 2018, the slogan "Democracy sold off Macedonia" was written on a wall of a public school which was occupied by students as a protest against the Prespa Agreement, while representatives of the Greek right-wing party were expressing their admiration for the students' "national sensitivity." One wonders whether this was one of the schools that got locked a few months ago by "concerned students and parents" to disallow the access of refugee students to education. It seems to me that the challenge for agonistic democracy is to ensure that schools do not lock out the critical knowledges of anti-racism, equality, social justice, and solidarity across/without borders, but actively resist the turning of history and history education into national/ist grand narratives.

I think the political performativity of the Prespa Agreement lies in activating counterhegemonic practices of democracy against manifestations of unleashed ethno-nationalism. It critically repositions the political body as a plural and open-ended demos of democracy across geopolitical and embodied borders rather than a nationally entrenched community. And this, I think, is an ever-present possibility, today turning into an important political imperative. Putting in action - theoretically and politically - new and more nuanced, intersectional and transversal, forms of critical transnationalism in this particular moment of advanced capitalism is a painfully crucial aspect of this transformative politics. This would perhaps provide a space in which the enduring violent effects of colonial, imperial, racialized, and nationalist sovereignties can be acknowledged and dismantled. 